\title{
Evaluating housing quality, health and safety using an Internet-based data collection and response system: a cross-sectional study
}

\author{
Mari Turunen*, Ari Paanala, Juha Villman, Aino Nevalainen, Ulla Haverinen-Shaughnessy
}

\begin{abstract}
Background: Typically housing and health surveys are not integrated together and therefore are not representative of population health or national housing stocks. In addition, the existing channels for distributing information about housing and health issues to the general public are limited. The aim of this study was to develop a data collection and response system that would allow us to assess the Finnish housing stock from the points of view of quality, health and safety, and also to provide a tool to distribute information about important housing health and safety issues.

Methods: The data collection and response system was tested with a sample of 3000 adults (one per household), who were randomly selected from the Finnish Population Register Centre. Spatial information about the exact location of the residences (i.e. coordinates) was included in the database inquiry. People could participate either by completing and returning a paper questionnaire or by completing the same questionnaire via the Internet. The respondents did not receive any compensation for their time in completing the questionnaire.

Results: This article describes the data collection and response system and presents the main results of the population-based testing of the system. A total of 1312 people (response rate 44\%) answered the questionnaire, though only 80 answered via the Internet. A third of the respondents had indicated they wanted feedback. Albeit a majority (>90\%) of the respondents reported being satisfied or quite satisfied with their residence, there were a number of prevalent housing issues identified that can be related to health and safety.

Conclusions: The collected database can be used to evaluate the quality of the housing stock in terms of occupant health and safety, and to model its association with occupant health and well-being. However, it must be noted that all the health outcomes gathered in this study are self-reported. A follow-up study is needed to evaluate whether the occupants acted on the feedback they received. Relying solely on an Internet-based questionnaire for collecting data would not appear to provide an adequate response rate for random populationbased surveys at this point in time.
\end{abstract}

\section{Background}

The characteristics of housing hold both social and economic importance for people, but more detailed information on how the quality of housing is linked to health and safety is limited [1,2]. Data collection methods are critical to the efficiency of population studies. Questionnaire-based study methods have been used in previous studies investigating occupant health and safety [3-7]. In

\footnotetext{
* Correspondence: mari.turunen@thl.fi

National Institute for Health and Welfare, Department of Environmental Health, P.O. Box 95, FIN-70701 Kuopio, Finland
}

today's communication society, web-based methods appear to be a natural development of methodology. Web-based questionnaires, usually in tandem with a paper questionnaire, have been used in several healthrelated studies $[8,9]$ with satisfactory response rates. Comparisons between responses to paper and Internet questionnaires [10] have shown them to yield similar results. However, in one Norwegian study [11] there was no meaningful increase in the response rate as a result of an option to respond via the Internet.

In Finland in 2007, 75\% of persons aged 15-74 used the Internet at least once a week [12], which means that

\section{() Bïomed Central}


a majority of people have access to the Internet. Thus we were encouraged to develop the option for an Internet response to the questionnaire along with the traditional paper form.

\section{Aims of the study}

The overall aim of the study was to develop a data collection and response system that would provide a means to assess the Finnish housing stock from the points of view of quality, health and safety. An option for respondents to reply via the Internet was included in the system. The system was also intended to ascertain people's information needs concerning housing and health, to explore spatial information in relation to occupant health issues, and to provide a tool for distributing information about important housing health and safety issues. The latter was accomplished by offering the respondents the possibility to receive individualised feedback based on their responses, which, together with an option to respond via the Internet, was expected to enhance the response rate.

In this article we describe the data collection and response system and present the main results of the population-based testing of the system.

\section{Methods}

\section{Questionnaire development}

Various sources contributed to the design of the questionnaire [13-15]. The questionnaire was tested among the Institute's employees, while a small city-based pilot study was also carried out as a part of one city's Suburb Project, prior to the nationwide study (data not shown). Some modifications were made to the questionnaire based on the comments received. The paper and internet questionnaire were identical and they were developed in parallel. On average it took 30 minutes to complete the questionnaire.

The final questionnaire included one hundred questions and it was divided into nine different sections as follows:

1) Respondent's information, seven items

2) Information about the place of residence, eight items

3) Information about the residence, 19 items

4) Hygiene, including drinking water, cleaning etc., 14 items

5) Physical and biological conditions, including ventilation, heating, dampness/moisture damage etc., 20 items

6) Chemical impurities, particles and fibres, 12 items

7) Safety, ten items

8) Welfare and health, seven items

9) Feedback, three items

\section{Sample size}

The sample size was estimated in order to achieve 95\% confidence level for the prevalence of common housing and health related factors, such as types of heating and ventilation systems, thermal conditions and perceived indoor air quality. At the end of 2007, there were approximately 2.73 million residences in Finland (Statistics Finland). Whilst the expected prevalence was not known with respect to all of the housing characteristics under review, using $50 \%$ for the estimated prevalence will result in the highest sample size, when required precision is set to $\pm 3 \%$. Therefore, the required sample size was approximately one thousand residences. In order to obtain the required data, a random sample of 3000 households was drawn from the Finnish Population Register Centre (FPRC) database.

\section{Ethical and data security issues}

The study plan was ethically evaluated and an approval was obtained from the Ethical Committee of the National Institute for Health and Welfare. Participation in the study was voluntary. Privacy protection was in accordance with the Finnish Personal Data Act [16] as well as the requirements of the National Institute for Health and Welfare.

\section{Questionnaire data}

A random sample of 3000 households was obtained from the FPRC. Persons aged $18-75$ (one person per household-dwelling unit) were selected for the sample. They each received a mailed invitation to participate in the study with a paper questionnaire and instructions. The respondents could either complete and return the paper questionnaire by regular mail or complete the same questionnaire via the Internet. The electronic questionnaire was implemented through an Internetbased software service [17] and it was linked to the project's website, which was hosted on the Institute's web server [18]. The online survey was accessed via a secure connection.

\section{Response system}

Depending on answers to specific questions regarding health and safety in the living environment, the respondents were given an option to receive individualised feedback. Feedback was available for 38 different items. For example, if someone responded that they had moisture or mould damage in their house, the feedback included general information on how such damage should be addressed. Technically, the response system was carried out with MySQL-database and PHP-scripting language. The response system analysed the questionnaire data taken from the Internet-based system and 
compiled individual feedback (sometimes for several issues) into a single document which was then sent to the respondent either by regular mail or by email as per the respondent's request.

\section{Questionnaire responses and data handling}

The response rate was $25 \%$ after the first mailing. The questionnaire material was sent for a second time to those who had not yet responded. With the second mailing, a one-page form was also sent, which we asked to be returned if the respondent was still unwilling to complete the main questionnaire. The form requested the main reasons for not responding. After the second mailing of the questionnaire (cumulative response rate $43 \%)$, we sent a postcard to those who still had not responded encouraging them to answer the questionnaire via the Internet. The final response rate was $44 \%$.

All data were entered into the Internet-based system either by the respondents or by the research personnel (with respect to the paper questionnaires). It was retrieved in CSV-format (comma-separated values), after which it was transferred to the SPSS-program and analysed with SPSS version 15.0. Descriptive statistics were drawn and $95 \%$ confidence intervals for point estimates were calculated using the formula:

$\left.\left.\mathrm{p}-1.96^{*} \sqrt{ } \mathrm{p}^{*}(1-\mathrm{p}) / \mathrm{n}\right) \leq \pi \geq \mathrm{p}-1.96^{*} \sqrt{ } \mathrm{p}^{*}(1+\mathrm{p}) / \mathrm{n}\right)$, where $\mathrm{p}$ is the percentage value of the sample and $n$ is the size of the sample.

\section{Spatial information}

We also included spatial information in the database: Exact locations (coordinates) of each respondent's home, as well as respondent's socioeconomic information and general information about the residential buildings (e.g. year of construction, size of the residence) were obtained from the FPRC. Data from the FPRC and the questionnaire were then merged (see Figure 1 for an example). The merged data allowed responses to be mapped geographically and to be used in parallel with other mapped information (e.g. road/traffic maps, radon maps). Results from the spatial analyses will be reported in detail at a later date.

\section{Results}

\section{Respondents}

Figure 1 shows the random sample and the respondents mapped to geographical location. Altogether, we received 1312 responses, with 80 responding via the Internet. As a result of the low number of Internet responses, the results have been split by type of response mechanism only in this section. Internet respondents were younger on average than those who returned the paper questionnaire and a larger percentage were men (Table 1$)$.

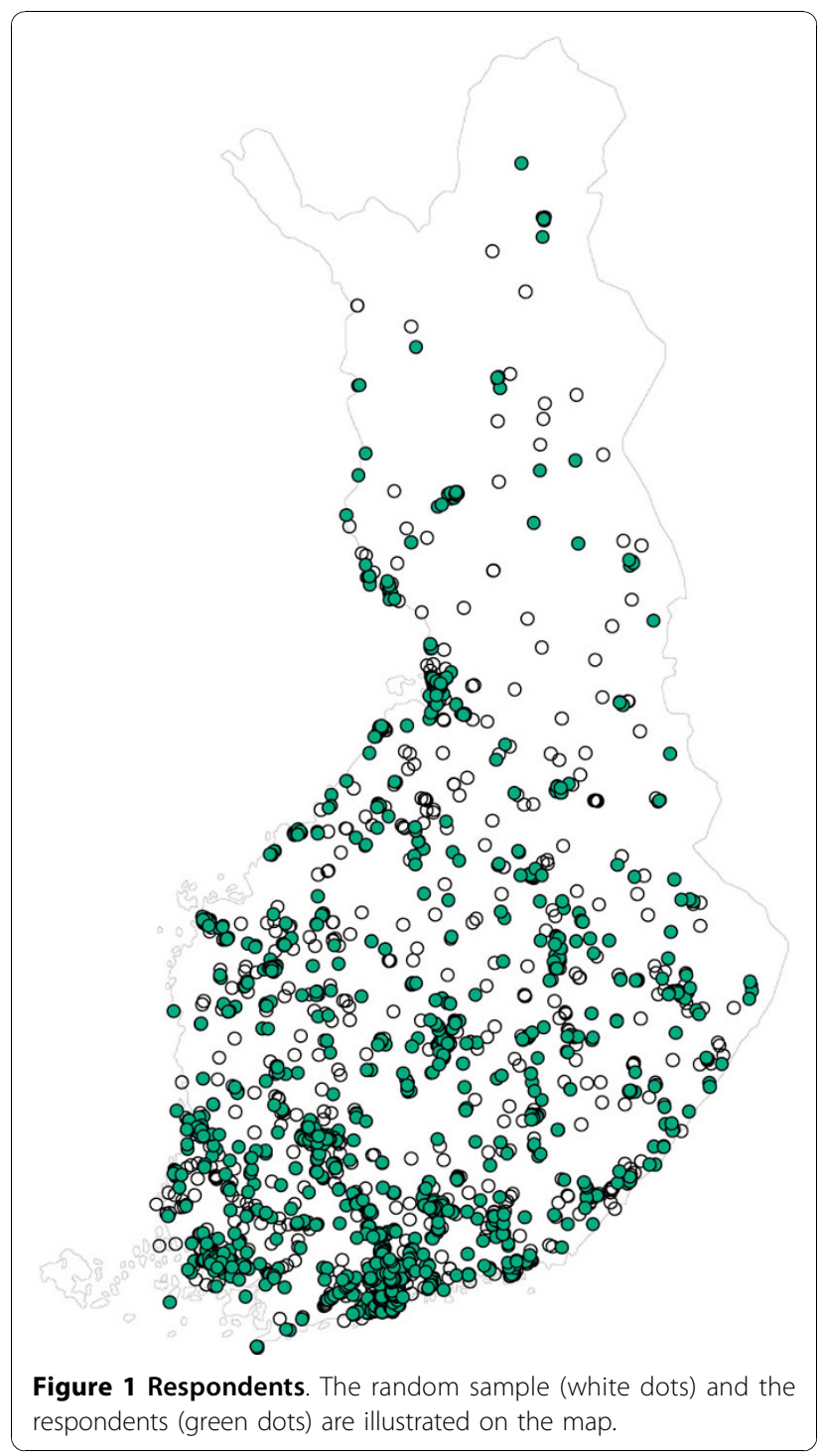

The overall response rate was $44 \%$. Table 1 shows that compared to random sample as a whole, the respondents were older on average and a larger percentage were women. Some $55 \%$ of the respondents were married ( $50 \%$ in the random sample). However, concerning housing characteristics (e.g. heating, ventilation), the respondents did not differ significantly from the random sample.

\section{Background information for respondents and their place of residence}

A majority of the respondents were living in suburban areas, as shown in Table 2. The respondents were mostly satisfied or quite satisfied with the possibilities/ public services in their local areas; public transportation was the most common cause of dissatisfaction (data not shown). Most respondents used a car to commute to 
Table 1 Background information for respondents

\begin{tabular}{|c|c|c|c|c|}
\hline & $\begin{array}{l}\text { FPRC* sample } \\
\quad(\mathrm{N}=3000)\end{array}$ & $\begin{array}{l}\text { All respondents } \\
\quad(N=1312)\end{array}$ & $\begin{array}{l}\text { Paper answers } \\
(\mathrm{N}=1232)\end{array}$ & $\begin{array}{l}\text { Internet answers } \\
\quad(\mathrm{N}=\mathbf{8 0})\end{array}$ \\
\hline \multicolumn{5}{|l|}{ Age } \\
\hline Years & 46.5 & 48.8 & 49.3 & 40.8 \\
\hline \multicolumn{5}{|l|}{ Gender $(N, \%)$} \\
\hline Female & 51.8 & 57.9 & 58.6 & 46.3 \\
\hline Male & 48.2 & 42.1 & 41.4 & 53.8 \\
\hline \multicolumn{5}{|l|}{ Marital status (N, \%) } \\
\hline Single & 35.6 & 15.2 & 14.5 & 26.3 \\
\hline Married & 50.3 & 55.1 & 55.8 & 45.0 \\
\hline Common-law marriage & 10.5 & 16.8 & 16.5 & 22.5 \\
\hline Other & 4.6 & 12.8 & 13.3 & 6.3 \\
\hline \multicolumn{5}{|l|}{ Heating } \\
\hline District heating & 41.1 & 40.7 & 40.8 & 38.8 \\
\hline Electricity & 26.2 & 28.7 & 28.7 & 30.0 \\
\hline Wood & 10.8 & 17.1 & 17.5 & 11.3 \\
\hline Oil heating & 19.9 & 13.9 & 13.8 & 15.0 \\
\hline Geothermal heat & 0.4 & 0.8 & 0.8 & 0.0 \\
\hline Mechanical ventilation & 39.5 & 37.8 & 37.3 & 46.3 \\
\hline
\end{tabular}

* Finnish Population Register Centre

work/school (41\%), followed by cycling (15\%), walking (14\%) and finally using public transportation (11\%). Figure 2 shows the average commute times.

Figure 3 shows the distribution of satisfaction with the housing by type. Over $91 \%$ of the respondents reported being satisfied or quite satisfied with their residence, but the most satisfied were those living in detached houses.

Respondents had been living on average for 13.7 years in their current home, as shown in Table 2. A majority of the residences were owner-occupied. The average size of the household per dwelling unit was 2.3 persons, which is slightly higher than expected based on the 2006 data from Statistics Finland (average 2.1 persons). About $86 \%$ of the respondents thought their home was large enough. However, about a fifth of respondents were planning to move within the next 12 months, and the main reason for moving was the size of the residence. The most common types of renovation carried out in the previous 12 months related to the roof, heating system, and/or plumbing/sewage system.

As presented in Table 2, almost $90 \%$ of the respondents were satisfied or quite satisfied with the indoor air quality in their home. Most of the respondents reported having either mechanical ventilation or mechanical exhaust; and $24 \%$ had natural ventilation. Some $11 \%$ reported that they had no ventilation at all and an equal percentage did not know what kind of ventilation they had. The most common primary heating system was district heating (for an explanation of district heating see abbreviations), while the second was electric heating, and the third was oil heating.

\section{Hygiene equipment and practices}

Table 3 shows that over $85 \%$ of the respondents received their drinking water from municipal water supplies. One in ten respondents had noticed some unusual taste, smell, sediment, or colour in their drinking water. Almost a third of the respondents had reported water supply disruptions within the last 12 months, most commonly caused by either repair work or faults in the water system.

A majority of the respondents did laundry, vacuuming and household waste removal at least weekly. In regard to general hygiene, $8 \%$ of respondents had seen signs of rodents indoors and $20 \%$ had seen signs of rodents in their yard.

\section{Physical and biological conditions}

A total of $57 \%$ of the respondents had fresh air intake vents in their bedroom and over $70 \%$ ventilated their residence daily by opening the windows as detailed in Table 4. Only a small proportion of respondents had a humidifier or an air purifier in their residence. In regard to combustion, $34 \%$ of the respondents had a fireplace, $23 \%$ a wood stove and $19 \%$ a wood-burning sauna stove in their home, with only $3 \%$ having a gas stove.

Eleven per cent reported that they had some serious water damage in their residence and $3 \%$ of those had 
Table 2 Background information about the respondents and their residences

\begin{tabular}{|c|c|c|c|c|}
\hline & \multicolumn{2}{|c|}{ Respondents } & \multicolumn{2}{|c|}{ Confidence interval $95 \%$} \\
\hline & $\mathrm{N}$ & & Lower Bound (\%) & Upper Bound (\%) \\
\hline \multicolumn{5}{|l|}{ Location of the residence } \\
\hline City centre & 181 & $14.0 \%$ & 12.1 & 15.9 \\
\hline Suburb & 530 & $41.0 \%$ & 38.3 & 43.7 \\
\hline Fringe area of the city & 154 & $11.9 \%$ & 10.1 & 13.7 \\
\hline Densely populated area & 203 & $15.7 \%$ & 13.7 & 17.7 \\
\hline Sparsely populated area, countryside & 225 & $17.4 \%$ & 15.3 & 19.5 \\
\hline Years in current residence (mean) & 1284 & 13.7 & 13.0 & 14.3 \\
\hline Owner-occupied & 990 & $76.0 \%$ & 73.7 & 78.3 \\
\hline Occupants per unit (mean) & 1312 & 2.3 & & \\
\hline Residence perceived large enough & 1119 & $86.0 \%$ & 84.1 & 87.9 \\
\hline Planning to move within a year & 221 & $17.4 \%$ & 15.3 & 19.5 \\
\hline \multicolumn{5}{|l|}{ Building characteristics } \\
\hline Flat roof & 218 & $16.9 \%$ & 14.9 & 18.9 \\
\hline Basement & 573 & $43.7 \%$ & 41.0 & 46.4 \\
\hline Energy efficient windows (triple glass or better) & 902 & $69.3 \%$ & 66.8 & 71.8 \\
\hline \multicolumn{5}{|l|}{ Most common types of renovations in the past 12 months } \\
\hline Roofing & 61 & $4.6 \%$ & 3.5 & 5.7 \\
\hline Heating system & 61 & $4.6 \%$ & 3.5 & 5.7 \\
\hline Plumbing/sewage system & 56 & $4.3 \%$ & 3.2 & 5.4 \\
\hline \multicolumn{5}{|l|}{ Pets } \\
\hline Dog or cat & 433 & $34.1 \%$ & 31.5 & 36.7 \\
\hline Satisfied or quite satisfied with the indoor air quality & 1169 & $90.1 \%$ & 88.5 & 91.7 \\
\hline \multicolumn{5}{|l|}{ Ventilation } \\
\hline Mechanical supply and exhaust & 334 & $26.2 \%$ & 23.8 & 28.6 \\
\hline Mechanical exhaust & 325 & $25.5 \%$ & 23.1 & 27.9 \\
\hline Natural & 311 & $24.4 \%$ & 22.0 & 26.8 \\
\hline \multicolumn{5}{|l|}{ Primary source of heating } \\
\hline District heating & 534 & $40.7 \%$ & 38.0 & 43.4 \\
\hline Electric heating & 377 & $28.7 \%$ & 26.2 & 31.2 \\
\hline Oil heating & 182 & $13.9 \%$ & 12.0 & 15.8 \\
\hline
\end{tabular}

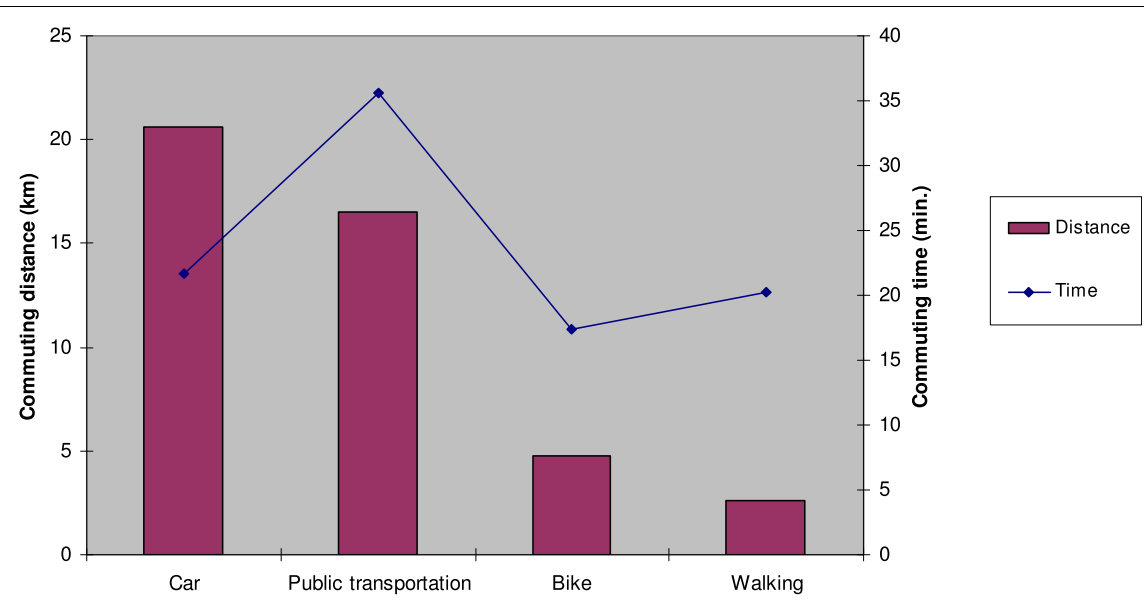

Figure 2 Commuting time and distance. The average times used for commuting. 


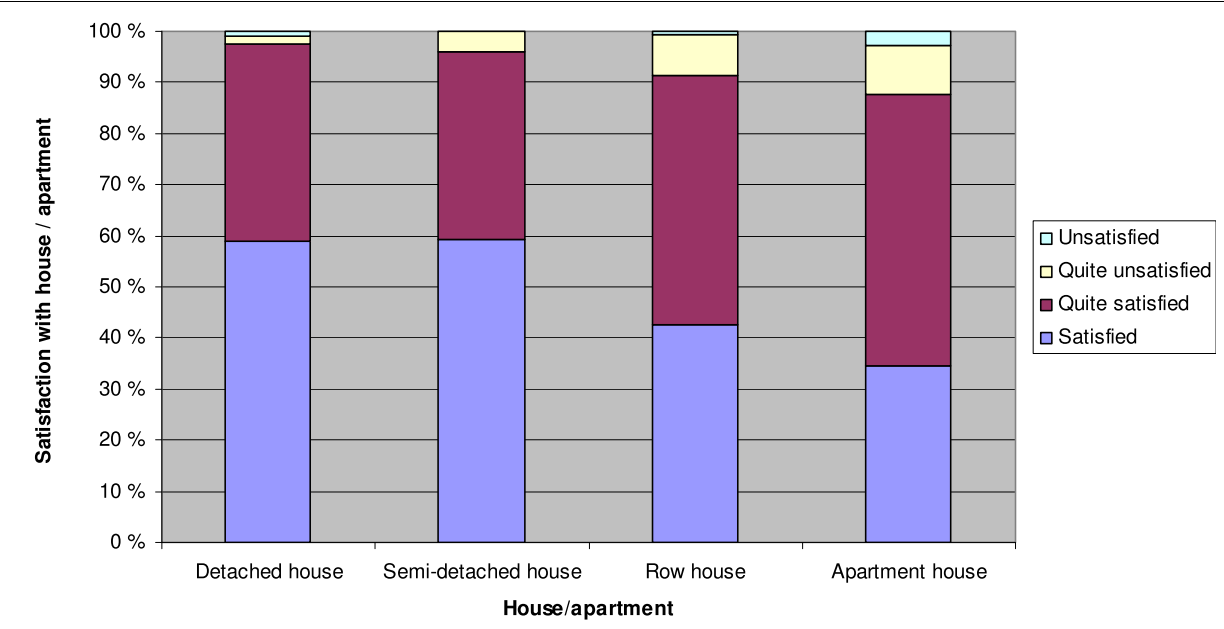

Figure 3 Satisfaction with current house versus type of house. The proportion of respondents satisfied with their residence in different types of residential buildings.

occurred within the last 12 months. Usually the damage had been repaired by removing the damaged materials or by drying the structures, although $2 \%$ reported that no actions had been taken.

At the time of the survey, moisture or mould damage was reported in $5 \%$ of the residences, a majority being described as local damage in the bathrooms. The main cause of moisture or mould damage was water from inside sources (plumbing leaks, etc.), while an almost equally common cause was water from outside sources (rain water, roof leaks, etc.).

A total of $39 \%$ of respondents reported some deficiencies in the lighting of their neighbourhood. The main source of daily noise was caused by road traffic, whereas the most common occasional/seasonal noise source was caused by yard work.

\section{Chemical impurities, particles and fibres}

About 2\% of the respondents reported smoking in their home on a daily basis as presented in Table 5. Over $28 \%$ were using insecticides and $17 \%$ were using herbicides in their household, but the usage was described as occasional. The most unpleasant outdoor odours that were reported related to traffic, farming, smoking, industry, and smoke; whereas the most common indoor odours related to food, sewers, stuffy air, and tobacco smoke. About $30-40 \%$ of the respondents had not noticed any odours in their home or in the neighbourhood.

Table 3 Hygiene equipment and practices

\begin{tabular}{|c|c|c|c|c|}
\hline & \multicolumn{2}{|c|}{ Respondents } & \multicolumn{2}{|c|}{ Confidence interval 95\% } \\
\hline & $\mathrm{N}$ & $\%$ & Lower Bound (\%) & Upper Bound (\%) \\
\hline \multicolumn{5}{|l|}{ Drinking water supply } \\
\hline Municipal water supplies & 1110 & 85.6 & 83.7 & 87.5 \\
\hline Own well & 125 & 9.7 & 8.1 & 11.3 \\
\hline Have noticed unusual taste or something else in the drinking water & 140 & 10.8 & 9.1 & 12.5 \\
\hline \multicolumn{5}{|l|}{ Water supply disruptions, due to } \\
\hline Repair work & 267 & 22.9 & 20.5 & 25.3 \\
\hline Faults in the water system & 68 & 6.1 & 4.7 & 7.5 \\
\hline \multicolumn{5}{|l|}{ Cleaning tasks performed weekly or more often } \\
\hline Taking trash out & 1259 & 99.6 & 99.3 & 99.9 \\
\hline Laundry & 1225 & 96.7 & 95.7 & 97.7 \\
\hline Vacuuming & 1167 & 91.3 & 89.8 & 92.8 \\
\hline \multicolumn{5}{|l|}{ Seen signs of } \\
\hline Rodents indoors & 98 & 7.5 & 6.1 & 8.9 \\
\hline Insects (herculean ant etc.) indoors & 137 & 10.4 & 8.7 & 12.1 \\
\hline
\end{tabular}


Table 4 Physical and biological conditions

\begin{tabular}{|c|c|c|c|c|}
\hline & \multicolumn{2}{|c|}{ Respondents } & \multicolumn{2}{|c|}{ Confidence interval $95 \%$} \\
\hline & $\mathrm{N}$ & $\%$ & Lower Bound (\%) & Upper Bound (\%) \\
\hline Fresh air intake vents in the bedroom & 735 & 57.3 & 54.6 & 60.0 \\
\hline Ventilation enhanced daily by opening the windows & 925 & 73.1 & 70.7 & 75.5 \\
\hline Humidifier & 67 & 5.1 & 3.8 & 6.4 \\
\hline Air purifier & 98 & 7.5 & 6.0 & 9.0 \\
\hline \multicolumn{5}{|l|}{ Combustion } \\
\hline Fireplace & 451 & 34.4 & 31.7 & 37.1 \\
\hline Wood stove & 300 & 22.9 & 20.6 & 25.2 \\
\hline Wooden sauna stove & 244 & 18.6 & 16.4 & 20.8 \\
\hline Gas stove & 44 & 3.4 & 2.4 & 4.4 \\
\hline Severe water damage in the past 12 months & 33 & 2.6 & 1.7 & 3.5 \\
\hline \multicolumn{5}{|l|}{ Damage repaired by } \\
\hline Removing the damaged materials & 99 & 7.5 & 3.6 & 11.4 \\
\hline Drying the structures & 94 & 7.2 & 3.3 & 11.1 \\
\hline No actions have been taken & 26 & 2.0 & -0.1 & 4.1 \\
\hline Current moisture or mould damage & 70 & 5.3 & 4.1 & 6.5 \\
\hline Size of the damage is large & & $0.1-0.5$ & & \\
\hline \multicolumn{5}{|l|}{ Main cause of the damage } \\
\hline Inside sources (plumbing leak etc.) & 30 & 2.3 & -0.7 & 5.3 \\
\hline Outside sources (roof leaks etc.) & 23 & 1.8 & -0.9 & 4.5 \\
\hline Cause unknown & 29 & 2.2 & -0.7 & 5.1 \\
\hline Lighting deficiencies & 524 & 39.9 & 37.2 & 42.6 \\
\hline Daily noise caused by road traffic & 276 & 22.4 & 20.1 & 24.7 \\
\hline Occasional/seasonal noise caused by yard work & 330 & 28.6 & 26.0 & 31.2 \\
\hline
\end{tabular}

Less than $1 \%$ of the respondents reported that there was asbestos in their living areas and $4 \%$ reported asbestos outside the living areas (for example in the basements of the block of flats). A few respondents reported elevated radon levels in their residence, but over $65 \%$ were unaware of the radon status for their place of residence.

\section{Safety, welfare and health}

Concerning the safety issues, Table 6 shows that over $96 \%$ of the respondents felt safe or quite safe in their neighbourhood. Fewer than $3 \%$ had felt personally threatened and fewer than $4 \%$ reported that their home had been broken into within the last 12 months.

Almost all the respondents had a fire alarm in their home and more than half had also a fire extinguisher and a first aid kit. The most common accidents that occurred in the respondents' home or neighbourhood were falls/ slips and fires. A quarter of respondents thought that their neighbourhood was accessible; whereas some $20 \%$ reported the neighbourhood was not accessible.

Concerning health issues, about $75 \%$ of the respondents perceived their health to be good or quite good.
The most common daily symptoms were respiratory symptoms (upper respiratory tract) and/or arthralgia; the second most common daily symptoms were general symptoms, eye and skin symptoms and muscular pain. Seven per cent had regular sleeping problems and 6\% reported daily lower respiratory tract symptoms.

Seven per cent of the respondents had doctor-diagnosed asthma. The most common allergies were hay fever and pet allergy. Within the last 12 months, 22\% had at least one episode of respiratory infections, $22 \%$ had visited a doctor and 15\% had missed work/school days due to respiratory infections.

\section{Information needs}

The questionnaire was divided into nine different sections as described in the paragraph 'Questionnaire development'. At the end of Sections 2-7, there was a question about information needs concerning the topics covered in the section. In addition, in Section 9 (Feedback) there was also a question related to the need for information/counselling services.

Table 7 shows that regarding the place of residence (Section 2), altogether $25 \%$ of the respondents felt that 
Table 5 Chemical impurities, particles and fibres

\begin{tabular}{|c|c|c|c|c|}
\hline & \multicolumn{2}{|c|}{ Respondents } & \multicolumn{2}{|c|}{ Confidence interval $95 \%$} \\
\hline & $\mathrm{N}$ & $\%$ & Lower Bound (\%) & Upper Bound (\%) \\
\hline \multicolumn{5}{|l|}{ Smoking inside the residence daily } \\
\hline Respondent him/herself & 32 & 2.5 & 1.6 & 3.4 \\
\hline Someone else & 27 & 2.2 & 1.4 & 3.0 \\
\hline Using insecticides & 336 & 28.5 & 25.9 & 31.1 \\
\hline Using herbicides & 161 & 16.7 & 14.3 & 19.1 \\
\hline \multicolumn{5}{|l|}{ Unpleasant odours outside } \\
\hline Traffic & 136 & 10.4 & 8.6 & 12.2 \\
\hline Farming & 128 & 9.8 & 8.1 & 11.5 \\
\hline Smoking & 119 & 9.1 & 7.4 & 10.8 \\
\hline Industry & 116 & 8.8 & 7.2 & 10.4 \\
\hline Smoke & 101 & 7.7 & 6.2 & 9.2 \\
\hline No odours outside & 395 & 30.1 & 27.5 & 32.7 \\
\hline \multicolumn{5}{|l|}{ Unpleasant odours inside } \\
\hline Food & 112 & 8.5 & 6.9 & 10.1 \\
\hline Sewer & 75 & 5.7 & 4.4 & 7.0 \\
\hline Stuffy air & 73 & 5.6 & 4.3 & 6.9 \\
\hline Tobacco smoke & 65 & 5.0 & 3.7 & 6.3 \\
\hline No odours inside & 587 & 44.7 & 41.8 & 47.6 \\
\hline \multicolumn{5}{|l|}{ Asbestos } \\
\hline In living areas & 10 & 0.8 & 0.3 & 1.3 \\
\hline Outside living areas & 52 & 4.1 & 3.0 & 5.2 \\
\hline Unaware of the asbestos & 362 & 28.8 & 26.3 & 31.3 \\
\hline \multicolumn{5}{|l|}{ Radon } \\
\hline Elevated radon levels & 9 & 0.7 & 0.2 & 1.2 \\
\hline Unaware of the radon & 830 & 65.8 & 63.2 & 68.4 \\
\hline
\end{tabular}

they would need more information about factors relating to health and safety issues in their local residential areas. In regard to health and safety issues in the dwelling itself (Section 3), some $27 \%$ of the respondents reported needing more information.

In relation to hygiene issues (Section 4), respondents most commonly reported a need for information about drinking water quality, waste water treatment, and rodents and other pests. Concerning physical and biological conditions in Section 5, the most commonly reported need was for information about ventilation, dampness/mould damage, and building maintenance issues.

In Section 6 (Chemical impurities, particles and fibres), respondents most commonly needed information about radon and indoor air pollutants, as well as asbestos. In Section 7 (Safety), respondents most commonly reported needing information about safety in the neighbourhood, security systems, and also about the safety of pedestrian paths.
Table 7 shows that in regard to information/counselling services (part of Section 9); most respondents reported needing information about complimentary counselling services and municipal services.

\section{Response system analysis}

About a third of respondents (33\%) wanted feedback based on their responses. Altogether, it was possible to get feedback on 38 question responses. As seen on Figure 4 , the maximum number of feedback per respondent was 19 feedbacks, and on average, feedback was given to 10 responses. Feedback was sent both by email

(34\%) and by regular mail (66\%). Those respondents who returned the paper questionnaire preferred to have the feedback by regular mail (71\%) rather than by email (29\%). On the contrary, a majority of the respondents who answered through the Internet were also more likely to want their feedback through email (80\%). As shown in Table 8 the most prevalent feedback requests (over $50 \%$ ) concerned issues such as ventilation, foul 
Table 6 Safety, welfare and health

\begin{tabular}{|c|c|c|c|c|}
\hline & \multicolumn{2}{|c|}{ Respondents } & \multicolumn{2}{|c|}{ Confidence interval $95 \%$} \\
\hline & $\mathrm{N}$ & $\%$ & Lower Bound (\%) & Upper Bound (\%) \\
\hline Feeling safe/quite safe in the neighbourhood & 1255 & 96.9 & 96.0 & 97.8 \\
\hline \multicolumn{5}{|l|}{ Within the last 12 months } \\
\hline Had felt personally threatened & 33 & 2.6 & 1.7 & 3.5 \\
\hline Residence had been broken into & 48 & 3.7 & 2.7 & 4.7 \\
\hline \multicolumn{5}{|l|}{ Safety equipment } \\
\hline Fire alarm & 1273 & 97.0 & 96.1 & 97.9 \\
\hline Fire extinguisher & 739 & 56.3 & 53.6 & 59.0 \\
\hline First aid kit & 683 & 52.1 & 49.4 & 54.8 \\
\hline \multicolumn{5}{|l|}{ Accidents in the neighbourhood } \\
\hline Falls/slips & 152 & 11.6 & 9.9 & 13.3 \\
\hline Fires & 59 & 4.5 & 3.4 & 5.6 \\
\hline \multicolumn{5}{|l|}{ Neighbourhood is } \\
\hline Accessible & 333 & 26.5 & 24.1 & 28.9 \\
\hline Not accessible & 245 & 19.5 & 17.3 & 21.7 \\
\hline Perceived health good/quite good & 972 & 75.7 & 73.4 & 78.0 \\
\hline \multicolumn{5}{|l|}{ Daily symptoms } \\
\hline Upper respiratory symptoms & 129 & 11.1 & 9.4 & 12.8 \\
\hline Muscular pain & 110 & 9.7 & 8.1 & 11.3 \\
\hline Skin symptoms & 104 & 9.3 & 7.7 & 10.9 \\
\hline Eye symptoms & 105 & 9.1 & 7.5 & 10.7 \\
\hline General symptoms & 101 & 8.8 & 7.2 & 10.4 \\
\hline Sleeping problems & 85 & 7.5 & 6.0 & 9.0 \\
\hline Lower respiratory symptoms & 75 & 6.7 & 5.3 & 8.1 \\
\hline Doctor diagnosed asthma & 98 & 7.7 & 6.2 & 9.2 \\
\hline \multicolumn{5}{|l|}{ Allergies } \\
\hline Hay fever & 212 & 17.8 & 15.6 & 20.0 \\
\hline Pet allergy & 125 & 10.9 & 9.1 & 12.7 \\
\hline \multicolumn{5}{|l|}{ Within the last 12 months } \\
\hline At least one episode of respiratory infections & 276 & 22.4 & 20.1 & 24.7 \\
\hline Has visited a doctor because of respiratory symptoms & 266 & 21.8 & 19.5 & 24.1 \\
\hline Had missed work/school days due to respiratory infections & 168 & 15.0 & 12.9 & 17.1 \\
\hline
\end{tabular}

taste or odour in the drinking water, radon, cleaning, pollen sources, and thermal conditions in the residence.

\section{Discussion}

In this study, the total response rate was $44 \%$, which is relatively good when compared with other self-administered occupant questionnaire studies that are related to health and safety issues [19-21]. General information about residences showed that the data collection and response system was able to collect information that was representative of the housing stock. Based on the 95\% confidence intervals, the estimates drawn based on this sample were $0.7 \%$ to $7.8 \%$ accurate.

Even though only a small proportion of answers came via the Internet, it is still considered a valuable tool to be used in questionnaire studies in the future. Its advantages include better controllability of the data and cost savings in mailing, data recording and filing tasks. Internet-based systems could potentially also be used in longitudinal studies in the future.

One reason for the low Internet response rate could be the length of the questionnaire. It might be easier for respondents to complete the paper version over several shorter periods than to complete it all at once (average response time about 30 minutes) as was necessary with the online survey. If it was possible to send a link directly to the respondents' email addresses, it could have improved the Internet response rate. Also those who responded via the Internet were typically younger, single, more educated, and 
Table 7 Information needs, including information/counselling services

\begin{tabular}{|c|c|c|c|}
\hline \multirow[t]{2}{*}{ Question } & & \multicolumn{2}{|c|}{ Respondents } \\
\hline & & $\mathbf{N}$ & $\%$ \\
\hline \multicolumn{4}{|c|}{ Do you need information concerning safety/healthiness issues of your living area? } \\
\hline & No & 936 & 71.3 \\
\hline & Yes & 322 & 24.5 \\
\hline \multicolumn{4}{|c|}{ Do you need information concerning safety and healthiness issues of your residence? } \\
\hline & No & 917 & 69.9 \\
\hline & Yes & 350 & 26.7 \\
\hline \multicolumn{4}{|c|}{ What information do you need concerning the following housing and health issues (hygiene part)? } \\
\hline & Drinking water quality & 341 & 26.0 \\
\hline & Rodents and other pests & 143 & 10.9 \\
\hline & Waste water treatment & 124 & 9.5 \\
\hline \multicolumn{4}{|c|}{ What information do you need concerning the following housing and health issues (physical and biological issues)? } \\
\hline & Ventilation & 316 & 24.1 \\
\hline & Dampness/mould & 253 & 19.3 \\
\hline & House maintenance & 224 & 17.1 \\
\hline & Heating system & 135 & 10.3 \\
\hline \multicolumn{4}{|c|}{ What information do you need concerning the following housing and health issues (chemical impurity-, particle- and fibre -issues)? } \\
\hline & Radon & 303 & 23.1 \\
\hline & Indoor air pollutants & 301 & 22.9 \\
\hline & Asbestos & 137 & 10.4 \\
\hline \multicolumn{4}{|c|}{ What information do you need concerning the following housing and health issues (safety issues)? } \\
\hline & Safety of the neighbourhood & 170 & 13.0 \\
\hline & Security systems & 167 & 12.7 \\
\hline & Safety of the walking trails & 111 & 8.5 \\
\hline \multicolumn{4}{|c|}{ Would you like to have individualised feedback based on your answers? } \\
\hline & No & 879 & 67.0 \\
\hline & Yes, by mail & 286 & 21.8 \\
\hline & Yes, by email & 147 & 11.2 \\
\hline \multicolumn{4}{|c|}{ What kind of information/counselling services would you need related to housing and health issues? } \\
\hline & Municipal services & 283 & 21.6 \\
\hline & Consultant services & 34 & 2.6 \\
\hline & Complimentary counselling services & 395 & 30.1 \\
\hline & Services of housing, construction and maintenance companies & 182 & 13.9 \\
\hline & Internet-based services & 234 & 17.8 \\
\hline & No need for such services & 546 & 41.6 \\
\hline & Something else & 14 & 1.1 \\
\hline
\end{tabular}

a larger proportion of them were male. It could be speculated that the Internet questionnaire may have improved the response rate for such sections of the population, whereas the 'typical' respondents have been older, married women. However, Internet-based questionnaires might currently fit better for certain target populations than the general public.

We were also able to obtain spatial data (exact location of the respondent's place of residence) in the study. It can be used to explore additional information about housing and health issues, for example in terms of visualisation and mapping (see Figure 1).

The place of residence is an important factor that could be connected to housing health and safety both directly and indirectly. For example, Wilson et al. [22] have reported that a place of residence (neighbourhood) has limited importance for determining health, but perceptions of neighbourhood environments (i.e., dislikes and to a lesser extent likes) are important for some health outcomes. 


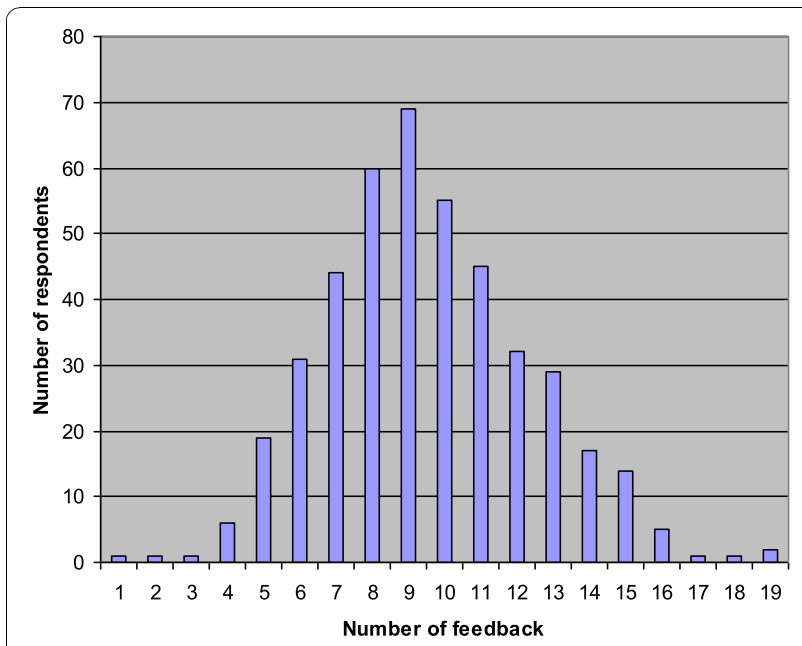

Figure 4 Distribution of feedback. Distribution of the number of feedback received by respondents.

Place of residence is naturally related to socioeconomic status, but it may also determine the availability of municipal water and sewage systems, services and transportation. Home location as such can have many implications for health and safety. For example, a home location that enables the occupants to commute by bike or to walk may promote their health more than many other 'healthy' housing parameters. A location that enables the occupants to use public transportation rather than a car may be environmentally friendly. However, public transportation also commonly results in dissatisfaction that may be reflected in users' responses about their living environments.

Of the respondents, $32 \%$ were living in blocks of flats, $44 \%$ were living in detached houses, $14 \%$ in row houses and $4 \%$ in semi-detached houses. According to Statistics Finland in 2005, 44\% of the households were living in blocks of flats, $40 \%$ in detached houses, and $14 \%$ in row

\section{Table 8 Ten most prevalent feedback topics related to questionnaire responses}

\begin{tabular}{ll}
\hline Rank & Feedback concerning \\
\hline 1 & Ventilation \\
\hline 2 & Foul taste or odour in the drinking water \\
\hline 4 & Radon \\
\hline 5 & Cleaning \\
\hline 6 & Pollen sources \\
\hline 7 & Cookers/fireplaces \\
\hline 8 & Security systems (inc. fire and burglar alarms) \\
\hline 9 & $\begin{array}{l}\text { Sources that can cause disturbance and/or pollution (for } \\
\text { example roads and factories) }\end{array}$ \\
\hline 10 & Asbestos \\
\hline
\end{tabular}

houses. Hence, more of this study's respondents were living in detached houses and fewer in blocks of flats compared to the statistical population data from 2005.

In addition to the type of residence, other important general housing health and safety aspects may include the size of residence and/or the occupant's perception of the size, as well as time spent living in the residence, plans to move, and renovation status. For example, occupancy per square meter is an objective way to assess crowdedness. We also asked whether the occupants perceived their home as large enough, although that element is more subjective. Time of living in a residence could be attributed to exposure time for certain environmental conditions, although they are subject to change. In addition to general life changes (relocating because of work, family situation, etc.), plans to move may be related to general dissatisfaction or observed defects in housing conditions. Completed or planned renovations may also be related to occupant satisfaction and well-being.

Drinking water quality is, in general, considered to be high in Finland. Over 85\% of residences are covered by municipal water and sewage services. However, about $10 \%$ of respondents had noticed an unusual smell, taste, sediment or colour in their drinking water. Moreover, almost one-third reported water supply disruptions, mainly due to repairs.

Regular cleaning is considered important for housing health and quality, even though there is not much information about typical cleaning practices and their frequency. House dust contains microbes such as bacteria and fungi [23-25], as well as other impurities. Pets can increase concentrations of various pollutants in the home and they may cause allergic and asthmatic symptoms [26]. In this study a majority of respondents reported performing basic cleaning tasks on a regular basis, such as taking the trash out and vacuuming. The Internet respondents did some of the cleaning tasks less frequently than those who returned the paper questionnaire, which may be related to factors such as gender, age, and socioeconomic status (data not shown).

According to new building regulations, residential buildings must have a sufficient ventilation/air exchange rate [27]. Modern building envelopes are becoming more airtight, so it is difficult to obtain a sufficient level of ventilation without a properly functioning mechanical system. Considering that fewer than $27 \%$ (Table 2) of the respondents reported having mechanical support and an exhaust ventilation system in their residence, only a part of the current housing stock would fulfil the criteria for sufficient ventilation. It could partly explain why a large part of the respondents enhance ventilation by opening windows, which in turn may result in energy loss, particularly during winter. 
In Finland, electric heating and oil heating are still common although renewable energy sources are generally supported [28]. While electric heating can also be renewable, in Finland only 15\% of electricity consumption was provided for by hydropower and only $0.3 \%$ by wind power in 2009 [29]. The proportion of renewable sources is expected to rise in the future, which may also have an effect on exposures to pollution originating from indoor and outdoor sources. Therefore it is important to also follow up trends in heating systems and usage (both primary and complementary) from an environmental health perspective.

Our results for the occurrence of moisture and mould damage (5\%) are a little lower than reported in other studies. For example, Kilpeläinen et al. found out that visible mould or damp stains or water damage was reported by $15 \%$ of respondents [30]; whereas in other studies the occurrence of moisture damage in residential buildings has previously been approximately $20-40 \%$ $[4,31]$. It is possible that the increase in the general awareness of the association between moisture and mould damage and health has led to improved maintenance and better repair of buildings in recent years. Interestingly, $19 \%$ of respondents reported specifically needing more information about moisture and mould related issues, so it still seems to be a matter of concern.

The health effects of noise have been widely studied, mainly in the form of annoyance and sleep disturbance, although cardiovascular effects have also been reported [32]. Lighting is considered to be an important factor related to the feeling of safety, and the lack of light during the winter has also been associated with depression [33]. From $20-30 \%$ of the respondents had experienced some disturbance because of noise or lack of light.

People are sensitive to unpleasant odours, which may cause disturbance, irritation symptoms, general symptoms and nausea. Odours have also been suggested as an important cause of worsening of asthma [34]. In this study, the most commonly reported unpleasant indoor odours were related to food, sewer gas, stuffy air, and tobacco smoke; they could also be related to insufficient or unbalanced ventilation.

Asbestos has been widely used in many building materials, especially during the 1960s and 1970s. Exposure to asbestos can cause lung cancer and asbestosis [35] for example. Less than $1 \%$ of respondents reported that there was asbestos in their living areas. However, $28 \%$ of the respondents did not know whether there was asbestos, while $10 \%$ reported needing more information about asbestos, so it may still be a matter of concern.

In Finland, indoor radon concentrations are among the highest in the world. The reasons for high concentrations are, among others, elevated uranium concentration in the ground and the cold climate [36]. Radon increases the risk for lung cancer [37]. In this study it was considered noticeable that over half of the respondents were unaware of the radon situation in their place of residence, and $23 \%$ reported needing more information about radon.

In regard to safety issues, a majority of the respondents felt safe or quite safe in their neighbourhood and fewer than $3 \%$ had felt personally threatened within the last year. According to another Finnish study from 2006, a total of $68 \%$ of the respondents had felt safe while walking in the centre of their hometown late on Friday and Saturday nights and about $14 \%$ had felt unsafe in their neighbourhood during weekend nights [38].

Approximately a quarter of the respondents felt that they would need more information about factors relating to health and safety issues in their local residential areas and also for their residence. Of the more specific housing and health related factors, the most frequently reported information needs related to drinking water quality (26\%), ventilation (24\%), indoor air pollutants and radon (23\%) and dampness/mould (19\%). In regard to the types of information/counselling services, respondents mostly reported needing more information about complimentary counselling services, with consulting services considered less useful.

The response system was an important part of this study. It gave us the means to provide important information about housing health and safety issues for the respondents. We also wanted to raise respondent's awareness and encourage them to look for more information concerning relevant housing issues. In addition, providing the incentive of feedback was decided with the aim of increasing the response rate. Research ethics are quite strict in Finland, which prevents us from offering monetary incentives, gift card, presents, etc. We asked the respondents to spend a significant amount of time in answering the questionnaires. Therefore it feels 'appropriate' to be able to offer something for them in return. This approach may therefore offer multiple benefits.

The feedback provided was developed as a combined effort linking the general guidance available on housing health and safety issues in Finland. The sources quoted included building codes [27], a housing and health guideline and guidebook [13,14], the Finnish Classification of Indoor Climate [39], and guidance material developed by The Radiation and Nuclear Safety Authority, the Finnish Allergy and Asthma Federation, the Pulmonary Association HELI, and other non-profit organisations.

Given that a third of the respondents opted to receive feedback for specific question items, it raises the question of whether the feedback option may have motivated occupants residing in 'bad' housing in particular to 
participate in the survey. We tested this briefly by comparing the results of those asking for feedback with those not wanting feedback. Although the general characteristics of these two groups were similar (no observed differences in age, gender, socioeconomic status, general building characteristics, etc.), there were statistically significant differences in some of the housing variables tested: feedback was requested more frequently among those who reported water damage, who had mechanical ventilation systems, and/or those who did not know about the radon situation in their place of residence. These results will be reported in detail elsewhere.

The response system was developed so as to automate the analysis and compiling work thereby reducing labour intensiveness and allowing the study personnel to send the feedback in a timely fashion. Unfortunately, we do not know for sure whether the respondents acted on the feedback they received; a follow-up study relating to this issue has been planned.

\section{Conclusions}

We have collected a largely representative housing database, which includes comprehensive information on housing quality and housing health and safety in Finland. This can be used to explore housing issues in relation to health and well-being. It appears that collecting questionnaire data while including the possibility of receiving feedback encourages some people to respond and request more information about their housing conditions. However, data collection relying only on the Internet does not appear to result in a good response rate in a general population sample at this point in time.

\section{List of Abbreviations}

CSV: comma-separated values; District heating: District heating is a system for distributing heat generated in a centralized location for residential and commercial heating requirements. It is produced in Combined Heat and Power (CHP) plants or heating plants. Customers receive heat from the hot water circulating in the heat distribution system and the heat is used in houses for the heating of rooms and service water, as well as for ventilation. District heating is the most common form of heating in Finland; FPRC: Finnish Population Register Centre; KTL: National Public Health Institute: MySQL-database: MySQL is a relational database management system. The MySQL-database runs on server which provides access to the database; PHP: PHP Hypertext Preprocessor is a scripting language which is used widely in web-based systems; SPSS: Statistical Package for the Social Sciences (SPSS is also name of a company); THL: National Institute for Health and Welfare

\section{Acknowledgements}

The project has been funded by the Finnish Ministry of the Environment, the Academy of Finland (grant 109062) and the Institute for Health and Welfare (THL) [previously National Public Health Institute (KTL)]. We would like to thank the project's Steering group: Timo Saarinen, Harri Hakaste and Raija Hynynen (Finnish Ministry of Environment), Risto Ruotsalainen (Finnish Allergy and Asthma Federation), Juhani Pirinen and Tuija Stambej (Pulmonary Association Heli), Anneli Juntto (University of Eastern Finland), Markku Rantama (The Finnish Real Estate Federation), Teija Meklin (Kuopio Innovation Oy). Also many thanks for developing questions and/or commenting the questionnaire to (in alphabetical order): Erkki Björk (University of Eastern Finland), Juho Halla-aho (THL), Helka-Liisa Hentilä
(University of Oulu), Anne Hyvärinen (THL), Sirpa Kasurinen (Helsinki University of Technology), Hannu Komulainen (THL), Jaana Kusnetsov (THL), Tarja Pitkänen (THL), Tuula Putus (Finnish Institute of Occupational Health), Marko Tainio (THL), Kristina Tiainen (THL), Pekka Tiittanen (THL), Jouni Tuomisto (THL), Asko Vepsäläinen (THL) and Pia Verkasalo (THL). The authors also wish to thank The Housing Finance and Development Centre of Finland for continuing the funding on our research related to housing health and safety.

\section{Authors' contributions}

MT participated in designing the questionnaire and the data collecting system, handling the questionnaires, performed part of the statistical analyses and wrote the first draft of the manuscript. AP participated in designing the questionnaire and the data collecting system, handling the questionnaires, performed spatial analyses, and participated in writing the manuscript. JV participated in designing the response system, sending feedback to the participants, and commenting the manuscript. AN participated in overseeing the study and in writing the manuscript. UHS participated in designing and co-ordinating the study and in writing the manuscript. All authors read and approved the final manuscript.

\section{Competing interests}

The authors declare that they have no competing interests.

Received: 1 July 2010 Accepted: 12 November 2010 Published: 12 November 2010

\section{References}

1. Report on the WHO Technical Meeting On Quantifying Disease From Inadequate Housing. [http://www.euro.who.int/_data/assets/pdf_file/0007/ 98674/EBD_Bonn_Report.pdf].

2. Housing interventions and health: A review of the evidence. [http:// www.nchh.org/LinkClick.aspx?fileticket=2lvaEDNBIdU\%3d\&tabid=229].

3. Toivola M: Personal exposure to microbial bioaerosols (1 M). Publications of the National Public Health Institute A 13 Kuopio, Finland: National Public Health Institute; 2004.

4. Haverinen U: Modeling moisture damage observations and their association with health symptoms. Publications of National Public Health Institute A 10 Kuopio, Finland: National Public Health Institute; 2002.

5. Koskinen O: Moisture, mold and health. Publications of National Public Health Institute A2 Kuopio, Finland: National Public Health Institute; 1999.

6. Baxter LK, Clougherty JE, Paciorek CJ, Wright RJ, Levy Jl: Predicting residential indoor concentrations of nitrogen dioxide, fine particulate matter, and elemental carbon using questionnaire and geographic information system based data. Atmos Environ 2007, 41(31):6561-6571.

7. Garcia-Algar O, Zapater M, Figueroa C, Vall O, Basagana X, Sunyer J, Freixa A, Guardino X, Pichini S: Sources and concentrations of indoor nitrogen dioxide in Barcelona, Spain. J Air Waste Manag Assoc 2003, 53(11):1312-1317.

8. Weisel CP, Weiss SH, Tasslimi A, Alimokhtari S, Belby K: Development of a Web-based questionnaire to collect exposure and symptom data in children and adolescents with asthma. Annals of Allergy Asthma \& Immunology 2008, 100(2):112-119.

9. Smith B, Smith TC, Gray GC, Ryan MAK, Team MCS: When epidemiology meets the internet: Web-based surveys in the millennium cohort study. American Journal of Epidemiology 2007, 166(11):1345-1354.

10. Ritter $P$, Lorig $K$, Laurent $D$, Matthews $K$ : Internet versus mailed questionnaires: A randomized comparison. Journal of Medical Internet Research 2004, 6(3):19-25.

11. Brogger J, Nystad W, Cappelen I, Bakke P: No increase in response rate by adding a Web response option to a postal population survey: A randomized trial. Journal of Medical Internet Research 2007, 9(5):e40.

12. Survey on ICT usage in households and by individuals 2007. [http:// www.stat.fi/til/sutivi/2007/sutivi_2007_2007-09-28_tie_001_en.html].

13. Asumisterveysohje (in Finnish). Sosiaali-ja terveysministeriön oppaita, 1/ 2003 Ministry of social affairs and health; 2003.

14. Asumisterveysopas (in Finnish). Ympäristö ja Terveys -lehti 2009.

15. Anna Strandell: The Residents' Barometer 2004. Residents' Survey on Residential Environments in Finland (in Finnish). Ministry of the Environment, Land Use Department; 2005. 
16. Finnish Personal Data Act. [http://www.finlex.i//en/laki/kaannokset/1999/ en19990523.pdf].

17. Digium, Internet-based software service. [http://www.digium.i//en/].

18. Web-site designated for the Altti-project. [http://www.thl.fi/fi/altti].

19. Kullberg A, Karlsson N, Timpka T, Lindqvist K: Correlates of local safetyrelated concerns in a Swedish Community: a cross-sectional study. BMC Public Health 2009, 9:11.

20. Hagerhed-Engman L, Bornehag CG, Sundell J: Building characteristics associated with moisture related problems in 8,918 Swedish dwellings. International Journal of Environmental Health Research 2009, 19(4):251-265.

21. Frisk M, Magnuson A, Kiviloog J, Ivarsson AB, Kamwendo K: Increased occurrence of respiratory symptoms is associated with indoor climate risk indicators - A cross-sectional study in a Swedish population. Respiratory Medicine 2007, 101(9):2031-2035.

22. Wilson K, Eyles J, Elliott S, Keller-Olaman S: Health in Hamilton neighbourhoods: Exploring the determinants of health at the local level. Health Place 2009, 15(1):374-382.

23. Kaarakainen $P$, Rintala $H$, Vepsalainen $A$, Hyvarinen $A$, Nevalainen $A$, Meklin T: Microbial content of house dust samples determined with qPCR. Science of the Total Environment 2009, 407(16):4673-4680.

24. Taubel M, Rintala H, Pitkaranta M, Paulin L, Laitinen S, Pekkanen J, Hyvarinen A, Nevalainen A: The occupant as a source of house dust bacteria. Journal of Allergy and Clinical Immunology 2009, 124(4):834-840.

25. Karkkainen PM, Valkonen M, Hyvarinen A, Nevalainen A, Rintala H: Determination of bacterial load in house dust using $\mathrm{qPCR}$, chemical markers and culture. Journal of Environmental Monitoring 2010, 12(3):759-768

26. Lindfors A, Wickman M, Hedlin G, Pershagen G, Rietz H, Nordvall SL: Indoor Environmental Risk-Factors in Young Asthmatics - a Case-Control Study. Archives of Disease in Childhood 1995, 73(5):408-412.

27. The National building code of Finland. [http://www.ymparisto.fi/default. asp? contentid=68171\&lan=en\#a3].

28. Government Decision on Energy Efficiency Measures (Finland). [http:// www.tem.fi/files/26317/

Government_Decision_on_Energy_Efficiency_Measures.pdf].

29. Energy Year 2009 - Electricity. [http://www.energia.fi/en/news/energy\% 20year\%202009\%20-\%20electricity.html].

30. Kilpelainen M, Terho EO, Helenius H, Koskenvuo M: Home dampness, current allergic diseases, and respiratory infections among young adults. Thorax 2001, 56(6):462-467.

31. Zock JP, Jarvis D, Luczynska C, Sunyer J, Burney P, Surv ECRH: Housing characteristics, reported mold exposure, and asthma in the European Community Respiratory Health Survey. Journal of Allergy and Clinical Immunology 2002, 110(2):285-292.

32. Maschke C, Niemann H: Health effects of annoyance induced by neighbour noise. Noise Control Engineering Journal 2007, 55(3):348-356.

33. Rosenthal NE, Sack DA, Gillin JC, Lewy AJ, Goodwin FK, Davenport Y, Mueller PS, Newsome DA, Wehr TA: Seasonal Affective-Disorder - a Description of the Syndrome and Preliminary Findings with Light Therapy. Archives of General Psychiatry 1984, 41(1):72-80.

34. Shim C, Williams MH: Effect of Odors in Asthma. American Journal of Medicine 1986, 80(1):18-22.

35. Selikoff IJ, Churg J, Hammond EC: Asbestos Exposure and Neoplasia. Ca-a Cancer Journal for Clinicians 1984, 34(1):48-56.

36. Weltner A, Mäkeläinen I, Arvela H: Radon mapping strategy in Finland. International Congress Series 2002, 1225:63-69.

37. Darby S, Hill D, Auvinen A, Barrios-Dios JM, Baysson H, Bochicchio F, Deo H, Falk R, Forastiere F, Hakama M, et al: Radon in homes and risk of lung cancer: collaborative analysis of individual data from 13 European casecontrol studies. British Medical Journal 2005, 330(7485):223-226.

38. Suominen P: Turvallinen Suomi 2006, Tutkimus suomalaisten turvallisuuskäsityksistä (in Finnish). Poliisin ylijohdon julkaisusarja 13 Helsinki, Finland: Sisäasiainministeriö, poliisiosasto; 2006.

39. Classification of Indoor Environment 2008. Target Values, Design Guidance, and Product Requirements. TR7. 2008.

\section{Submit your next manuscript to BioMed Central and take full advantage of:}

- Convenient online submission

- Thorough peer review

- No space constraints or color figure charges

- Immediate publication on acceptance

- Inclusion in PubMed, CAS, Scopus and Google Scholar

- Research which is freely available for redistribution 